\title{
Children's Literature, Domestication, and Social Foundation - Narratives of Civilization and Wilderness Book Review
}

Sarat K. Colling, Independent Researcher, Hornby Island, Canada

Children's Literature, Domestication, and Social Foundation: Narratives of Civilization and Wilderness Layla AbdelRahim

(C) 2015 by Routledge

$274 \mathrm{pp}$.

$\$ 143.65$

ISBN 0415661102

"[C]ivilized reason begets monsters, for through stories that try to explain our raison d' être, it weaves a narrative of captivity, servitude, and death" (AbdelRahim, p. 23).

Anthropologist Layla AbdelRahim's 2015 book Children's Literature, Domestication, and Social Foundation: Narratives of Civilization and Wilderness is about the underlying premises that inform the perspective with which we view the world and thus imbue both our scientific and fictional narratives. The book is as much a study of the methodology involved in epistemic production as it is an examination of the foundational stories of origins, both scientific and religious, and children's literature, which constitutes an "anthropological informant in the field" (AbdelRahim, p. 2). By analyzing children's literature "as knowledge, culture, and social foundation," the book investigates how scientific and fictional human and nonhuman narratives inform culture, social life, and fiction, and how fiction informs science and influences the world (AbdelRahim, p. 20).

AbdelRahim begins by problematizing the book's grounding terms in the introduction: "culture," "wilderness," "wildness," "civilization," "colonization," and "literature." Proceeding "from the Word to the World," this book is divided into three well-organized chapters, dedicated to epistemology, ontology, and anthropology. Throughout the book, she asks how a nexus of domestication, colonization, and literature plays out in the "sacred texts" of our societies. This question is explored through analysis of the various socio-economic and political systems in wilderness and civilization and by tracing these underlying premises in the foundational narratives of civilization, such as religious, scientific, and literary. This analysis is then applied to the various children's stories that are examined in subsections, with titles such as, "Winne-ther-Pooh as Other," "Taming Children's Inner Landscape and Other Wild Things," "Do Children Dream of Cyborg Love," and "Anne's Choice," to name a few, along with other studies that bring different works of art and theory into conversation.

The first technology of domestication, she suggests, was language and disciplinarity. Literature has been an integral part of the technology of domestication for thousands of years. Civilized narratives, from ancient Japanese and Chinese works, Alice in Wonderland, and Winnie-the-Pooh, 
to The Canterbury Tales and The Arabian Nights, continue to preserve socio-economic inequality and relationships of debt while rationalizing murder through ontological reasons for killing. Acts of violence are justified if carried out against disobedient individuals.

AbdelRahim challenges the widely-held assumption of civilized narratives that wild life is dangerous. Relying on palaeontological finds and anthropological research, she observes that human civilization emerged only 10,000 years ago and quickly resulted in the Holocene Extinction or, in other words, human-made destruction of life. Accordingly, it implies that older species than humans have possessed the complex intelligence necessary to coexist. Unlike in a state of wilderness, civilization attributes a utilitarian purpose of the world, exemplified in the hierarchical food chain, with the human animal depicted as the ultimate predator. Remarkably, even anthropology as a discipline sets humans apart from other animals. The author attributes the origins of this narrative to the assumption that the carnivorism of Paleolithic hunters led to larger brains and an improved socio-economic organization. However, in the introduction, she discusses palaeoanthropological evidence showing that, in fact, Homo sapiens had much smaller brains than other kindred lineages (AbdelRahim, pp. 12-13). Furthermore, she argues, hunting led to the Agricultural Revolution, which, in turn, enabled the emergence of civilization. At that moment, the critical shift in human consciousness occurred. Humans, who used to perceive themselves as an organism among many others, began to distinguish themselves from others. This knowledge institutionalized an anthropocentric worldview that justified the domestication, control, consumption, management, killing, and ownership of nonhumans by humans. The shift in self-consciousness revolutionized subsistence strategies and eventually enabled the institutionalization of violence. There is no system of murder in the wilderness, contrary to civilization.

The first part of the book is dedicated to examining the origins and function of language, symbolic thought, and narratives. The author argues that for the civilized mythology to continue, humans must be domesticated and accept the meta-narrative of civilization. A key site for socialization is fictional and scientific narratives, especially those written for children. Literature has become one of the most important forces of socialization, and children's stories play a key role in socializing young individuals into exploitative and hierarchical social relationships (AbdelRahim, p. 230). The book examines how civilized societies' underlying premises are dispersed into culture through science, religion, and perhaps most effectively through children's literature and, along with material realities, shape the experiences of children. They structure children's inner landscapes and turn them into "human resources." It is a transformation that is required to keep the system going, and the costs are high "in terms of loss of empathy, understanding, and quality of experience" (AbdelRahim, p. 18). As AbdelRahim notes, "Children's culture presents a particularly potent nexus of narratives since children are born wild and it takes years to domesticate them through narratives and pedagogies" (p. 32). The fundamental stories in our society - those that inform our conceptions of education, health, diet, social justice, property, worship, obedience, knowledge, nation, and our daily movements —are often stories we read as youth. Their messages are internalized and often remain with us, unquestioned and uncontested. They are passed on from one generation to the next.

While many fictional and scientific stories are analyzed and compared, AbdelRahim hones in on three globally influential works by children's authors. These are Winnie-the-Pooh, The Adventures of Dunno and Friends, and the Moomin series. She demonstrates why these stories illustrate three social-political ideologies, paradigms, and contexts from which they arose-capitalist, socialist, and anarchist - that are rooted in ontologies of civilization and wildness and their underlying premises. Winnie-the-Pooh, by A.A. Milne, was written during the era of the British Empire and presents a capitalist world of agricultural civilization, in which humanism breeds sterility. The Adventures of Dunno and Friends, a trilogy by Nikolai Nosov, was written during the Soviet era (and was the first book AbdelRahim learned to read) and depicts an anarchist-socialist community among a wide range of other socio-economic systems. The Moomin series, by Tove Jansson, for which writing began in Finland during World War II, presents wild and harmonious relationships in an anarchistic society. 
For AbdelRahim, reading Jansson's narrative of wilderness helped loosen the grip of civilization by demonstrating a world of diversity, harmony, chaos, spontaneity, and symbiosis in which the characters thrive. Based on cooperation and mutual aid, the Moomin world is more Kropotkinesque than Darwinian. In fact, followers of Peter Kropotkin's Mutual Aid: A Factor of Evolution (1902) will recognize the underpinnings of anarchism in this study. AbdelRahim discusses numerous ways the world would have looked very different if the works of Kropotkin, who posited that wilderness was conducive and favoring for life, had been celebrated and practiced, rather than those of Charles Darwin. As various living beings employ distinctive strategies, she illustrates the differences between mutualistic cultures on the one hand, and commensalitic, amensalistic, and parasitic ones on the other.

AbdelRahim demonstrates how, with a few exceptions, such as the wild-premised Moomin books, children's literature projects three myths of civilization "as self-evident truths." First, civilization is assumed to be a natural part of evolution or the fulfillment of a divine purpose only available to human beings. Second, wilderness is projected as a dangerous, destitute, frightening place, where death and illness are always around the corner, while civilization offers the antidote through safety and a long, healthy life for its domesticated inhabitants. Finally, civilization is aligned with compassion and morality, while wilderness is cruel, amoral, and ruthless (AbdelRahim, p. 202). These false assumptions about the benefits of civilization and the destitution of wilderness are internalized and have material consequences. They are leading to many social, economic, and environmental problems today, in a world where hierarchy, separation, dispossession, and differentiation are legitimized (AbdelRahim, p. 6).

The argument that many narratives comply with civilized mythology and perpetuate it is compelling. The facts and assumptions that underlie society are inscribed in larger, transcendent narratives. Even those which claim to transgress the boundaries of wild/domestic often remain caged in the meta-narrative of domestication and civilization:

Even through a narrative that promises to venture beyond the civilized frontiers into a new and untamed territory, where meaning is discarded, and paradigms are shattered, these stories often remain the vehicle for the larger narrative that reconfirms the institution of civilization, its language, mythology, and predatory violence. (AbdelRahim, p. 21)

To support her position, AbdelRahim also draws on several studies including Jack Zipes (1983) examinations of the Weimar Republic's fairy tale nationalization project and how America's consumer and capitalist culture is perpetuated through children's literature. Her own anthropological work entitled The Encounter about Somali immigrants in Sweden and the Swedish medical/social system also proves relevant, demonstrating how different domesticated contexts have the same civilized mechanisms in operation (AbdelRahim, p. 74).

AbdelRahim, who has a diverse, multilingual, interracial, and intercontinental background, applies her own experience to the text (which, as she explains, is structured by her life journey). She was born in Moscow and grew up experiencing life in multiple worlds. Most significantly for this text, she was connected to wilderness while living with her grandparents in a small Russian village. She explains that "we embody narratives and live through them"; to fully comprehend a text, the researcher goes beyond mere observation (AbdelRahim, p. 28). The children's texts that she focuses on were part of her childhood, making this exploration of civilization and wilderness both a "study of the self" and, due to time, distance, and geography, a comparative ethnographic study that transcends genre and text, and connects the past and present (AbdelRahim, pp. 30-34). In fact, studying children's narratives is a project we all benefit from, as we are all born untamed and are later introduced to narratives that influence our ways of being. Whether human or nonhuman, all animals are reluctant to forgo their wildness, despite thousands of years of domestication. 
This book is relevant across disciplines. It gets to the root of many socio-environmental problems, provides a useful analysis of how these systems operate, and offers solutions for change. It will appeal to those interested in the connection between children's literature and socialization and the transmission of "civilized memes and genes" through literacy. It is a much-needed addition to studies in areas such as Education, Geography, Environmental Studies, Philosophy, Comparative Literature, English literature, Anthropology, Globalization, Sociology, and Interdisciplinary Studies. For both educators and activists, it opens the door to new teaching tools, e.g., the critical tools to interrogate the narratives we accept and then present to children-some of them appearing deceptively innocuous-and revaluates whether they are really serving us.

The study will also be of interest to Critical Animal Studies scholars, with topics such as the transformation of humans and nonhumans into resources, and how narratives can help overcome speciesism. As AbdelRahim claims, the institutions of civilization are rooted in classism, sexism, racism, and speciesism. In her words, "this intersectionality works to solidify oppressive and discriminatory practices and the epistemological classification system on which this paradigm is built has serious material repercussions for whole classes of beings" (AbdelRahim, p. 9). One of the purposes of differentiation between species is to legitimize unequal power relations. Human beings construct stories that prioritize human life at the expense of nonhuman animals and nature. From the perspective of civilization, wild creatures are to be tamed and, subsequently, exploited and consumed.

According to AbdelRahim, civilized epistemology introduced the categories which encompass the totality of the experiences of its members, such as "cattle" (to serve the human class as food) and "prey." Hence, animals are defined according to their utility to humans. Fundamentally, those epistemological classes were then translated into socio-economic classes, distinguishing the agents, or those who own, know, and possess, from those who are known, owned, and exploited. This narrative allows that, like other animals, some humans become dispossessed, consumed, and exploited. A drive to control resources resulted in the emergence of private property and cities as spaces built for the needs of one species and separate from all that is wild. This, in turn, enabled the processes of colonization, in which the human predator, who exploits resources and energy, lived in one place while controlling and consuming a remote land base (AbdelRahim, pp. 14-20).

After we identify whether a text is civilized or wild, the question then becomes, will we continue to renounce our wildness like several of the protagonists in the stories analyzed, or will we create new stories that reframe our worlds and allow wild things to grow? Looking upon the massive destruction of the planet today, the radical restructuring-such as that which is prescribed in this book-is needed more than ever. The book brings a message of hope: It is not too late to re-wild our lives. The goal is to rewild our relationships to ourselves and others by first rooting ourselves in mutualism and by ensuring that we feed our minds and others with stories that nourish our imaginations and lives. It is a powerful suggestion. Creative thought can help us form a new social foundation. Indeed, as AbdelRahim shows, we can dare to adventure into the wild and practice presence, empathy, and compassion. In such spaces, "we can come to share new stories by living them instead of having one story live our dreams" (AbdelRahim, p. 236). Wild narratives bring genuine possibilities for diversity, community, and life.

Children's Literature, Domestication, and Social Foundation is richly comparative, experientially compelling, informative, thought-provoking, and well-supported. Digging deep into our social foundations, it both critiques and celebrates science and folklore, while providing a new perspective that is both a treat and a challenge to those who love literature. It is a compassionate call to the readers to transform their surroundings in the spirit of wildness, love, and peace. This world is much like the borderless home that Jansson dreams of, "where sorrow can be cured by acceptance, where healing comes through movement and Moominmamma's love, and where Snufkin destroys the incarcerating power of literacy and language and reinstates authentic communication and understanding with his 
song" (AbdelRahim, p. 109). To truly become free, it is imperative to re-examine the stories that have made up our lives, indoctrinated us into a war on wilderness, and caused alienation from each other and our own wildness within. How would life be different if we moved from ordered civilization to a wild, harmonic chaos? As AbdelRahim asks, would children still need to be told "...that a world of careless play and agency over one's mind and imagination are to be forsaken when they move on to the 'real' world?" (p. 220). 
International Journal of Social Ecology and Sustainable Development

Volume 10 • Issue 1 • January-March 2019

\section{REFERENCES}

Kropotkin, P. (1902). Mutual Aid: A Factor of Evolution. London: Free Press.

Sarat K. Colling has a master's degree in Critical Sociology from Brock University. Her books include Love and Liberation (2012) and Animali in Rivolta (Italian) (2017). She has contributed to several anthologies on the topic of animals, environment, and social justice. She is currently writing a book about the transgressions of animals across human-constructed borders. Sarat lives on Hornby Island, BC, Canada. 